PALEO

Revue d'archéologie préhistorique

$18 \mid 2006$

Varia

\title{
AMS dating of a recently rediscovered juvenile human mandible from Solutré (Saône-et-Loire, France)
}

Datation AMS d'une mandibule récemment redécouverte d'un humain juvénile de Solutré, Saône-et-Loire

\section{William Pestle, Michael Colvard and Paul Pettitt}

\section{OpenEdition}

\section{Journals}

\section{Electronic version}

URL: http://journals.openedition.org/paleo/772

DOI: $10.4000 /$ paleo.772

ISSN: 2101-0420

\section{Publisher}

SAMRA

\section{Printed version}

Date of publication: 1 December 2006

Number of pages: 285-292

ISSN: $1145-3370$

\section{Electronic reference}

William Pestle, Michael Colvard and Paul Pettitt, « AMS dating of a recently rediscovered juvenile human mandible from Solutré (Saône-et-Loire, France) », PALEO [Online], 18| 2006, Online since 23 April 2009, connection on 07 July 2020. URL : http://journals.openedition.org/paleo/772 ; DOI : https://doi.org/10.4000/paleo.772

This text was automatically generated on 7 July 2020. 


\title{
AMS dating of a recently rediscovered juvenile human mandible from Solutré (Saône-et- Loire, France)
}

\author{
Datation AMS d'une mandibule récemment redécouverte d'un humain juvénile \\ de Solutré, Saône-et-Loire
}

William Pestle, Michael Colvard and Paul Pettitt

The authors wish to thank Jonathan Haas and Bennet Bronson of the Field Museum of Natural History for access to the Solutré collections, Isabel Tovar and Laure Dussubieux for their immense aid in matters of translation, and Jill Seagard for her illustrations. The authors also would like to acknowledge the very useful comments of two anonymous reviewers. This article is dedicated to Christian Rodriguez, who assisted by providing a comparative, albeit living, juvenile human mandible.

\section{Introduction}

1 The site of Solutré $\left(46^{\circ} 18^{\prime} \mathrm{N}, 4^{\circ} 42^{\prime} \mathrm{E}\right)$, located in the department of Saône-et-Loire, approximately $10 \mathrm{~km}$ west of Mâcon, is most widely known as the eponym for the Solutrean lithic industry and phase of the Upper Paleolithic (fig. 1). The majority of cultural materials recovered from excavations over nearly 150 years were excavated from a gentle slope located to the south-east of a nearly $500 \mathrm{~m}$ tall limestone escarpment, the Roche de Solutré, in areas known respectively as the Crot-du-Charnier, Terre Communale, Terre Seve, and Terre Souchal (Combier 2002). 
Figure 1 - Location of the Solutré site (drawing J. Seagard). Figure 1 - Localisation du site de Solutré (dessin de J. Seagard).

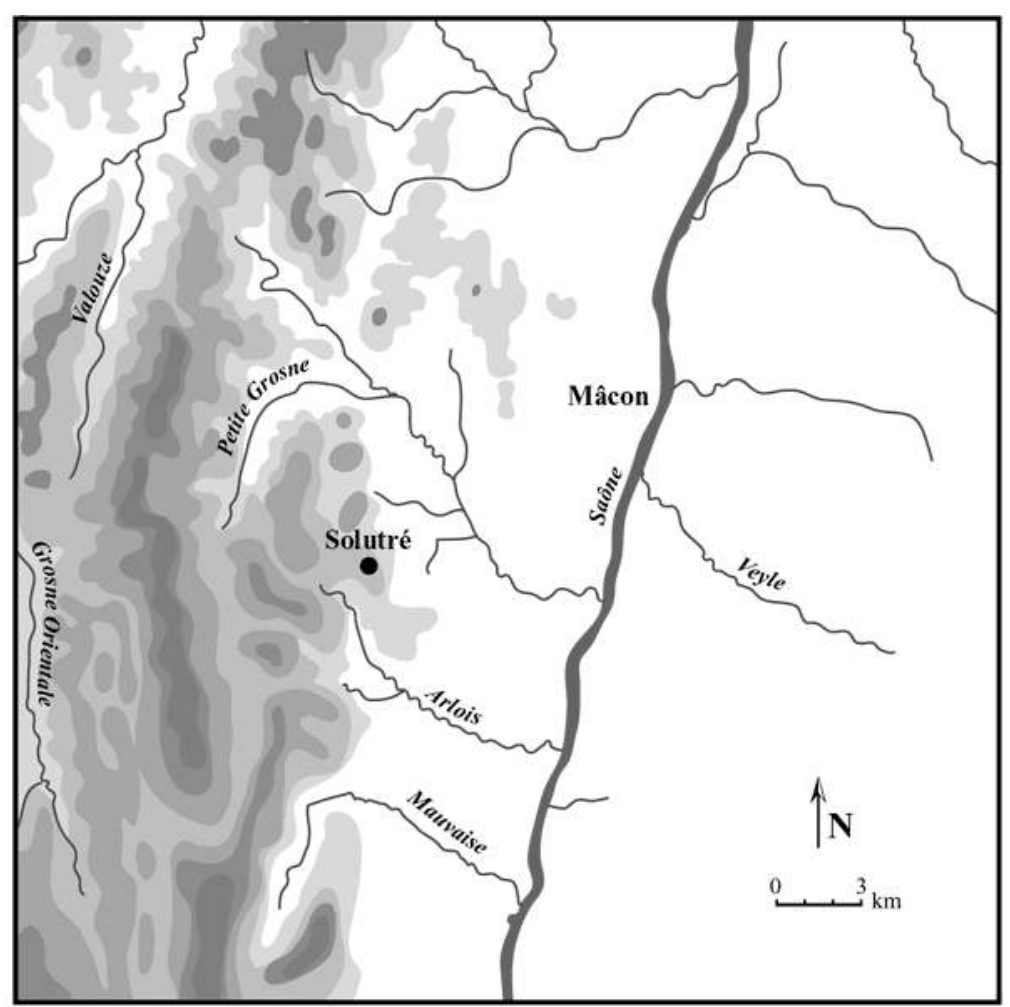

2 The earliest excavations at Solutré began in 1866 under the direction of Adrien Arcelin and Henri Testot-Ferry, with efforts focused on the so-called "horse magma", a layer of accreted horse bones, and several foyers du renne, hearths ostensibly of the l'age du renne, or the Solutrean (Combier 2002). Between 1873 and 1895, Arcelin, with the aid of Abbé Ducrost, conducted further excavations at the site, which identified three successive culturally distinct layers of occupation, Solutrean, Gravettian, and an unattributed basal stratum, which was subsequently defined in 1907 by Abbé Breuil as Aurignacian. Continued work in the 20 th century by the University of Lyon and Jean Combier on behalf of the CNRS have combined to produce a fairly fine-grained understanding of the complex nature of over 20,000 years of occupation and activity at the site of Solutré (Combier 2002). What is lacking from the site, however, are definitively Solutrean period human remains, the discovery of which would allow useful and meaningful bio-cultural inferences about the lifeways of the ancient inhabitants of Solutré to be made. Numerous "pretenders", human skeletal remains thought to be of Solutrean (or older) vintage, have been brought forward (e.g. Arcelin 1878), but, to date, none have withstood serious scientific scrutiny (Riquet 1955). The legitimacy of a recently re-discovered specimen of human skeletal material from Solutré is examined herein in the hopes that its verifiable antiquity might help to fill a gap in our knowledge base of life in Upper Paleolithic Southwestern Europe.

\section{Specimen history}

In 1896, at the same time as Arcelin and Ducrost were performing stratigraphicallyoriented and rigorously documented work on the Crot-du-Charnier, the excavator of 
what would come to form the Field Museum's collections, a M. Veillerot, working on behalf of the Union Parodiènne, was excavating in a more slapdash fashion just a few meters to the west (Combier 2002 ; Dalton 1968). To date, the almost total absence of documentation for Veillerot's excavation has impeded interpretation of the resulting collection of material culture, a portion of which now resides at the Field Museum of Natural History in Chicago, Illinois. The only surviving account of the 1896 work is that of a Monsieur O. Vauvillé, a member of the Societé d'Anthropologie de Paris, who visited the site for one day in May of 1896, and who recorded his observations in a report to the Societé. From this report, however brief, several important aspects of the 1896 excavation can be reconstructed, thereby providing the resulting materials with some degree of archaeological context.

Figure 2 - Section of the Crot-du-Charnier after Arcelin 1890 (drawing J. Seagard). Figure 2 - Section du Crot-du-Charnier d'après Arcelin 1890 (dessin de J. Seagard).

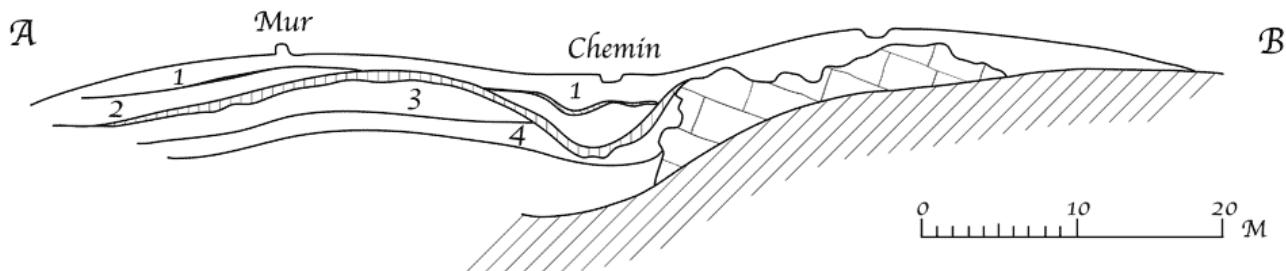

4 First, Vauville states that the single trench was located “...au-dessous et contigu, du bout Est, au mur de cloture qui est vers l'Ouest du lien dit le Crot-du-Charnier, et à l'Ouest du chemin montant de Solutré au gisement" (Vauvillé 1896). We associate the enclosure wall and path Vauvillé describes with the mur and chemin depicted in the A-B section drawing of the Crot-du-Charnier published in Arcelin 1890 (fig. 2). In turn, transposing these features, and the distance between them, onto the A-B line of the plan drawing of Arcelin 1890 (fig. 3), allows us to surmise that Veillerot's trench may have been located in the shaded area of fig. 3, to the west of the Crot-du-Charnier (note 1). In 1896, this area would have been, as Vauvillé described the trench's location, a relatively undisturbed portion of the site. Finally, from Vauvillé we know the size of the trench (approximately $45 \mathrm{~m} 2$ ) and that it included the remains of at least one wellstratified hearth (Vauvillé 1896). Beyond this fleeting reference, little is known of the stratigraphy of the 1896 trench. 
Figure 3 - Plan of the Crot-du-Charnier after Arcelin 1890 (drawing J. Seagard). Figure 3 - Plan du Crot-du-Charnier d'après Arcelin 1890 (dessin de J. Seagard).

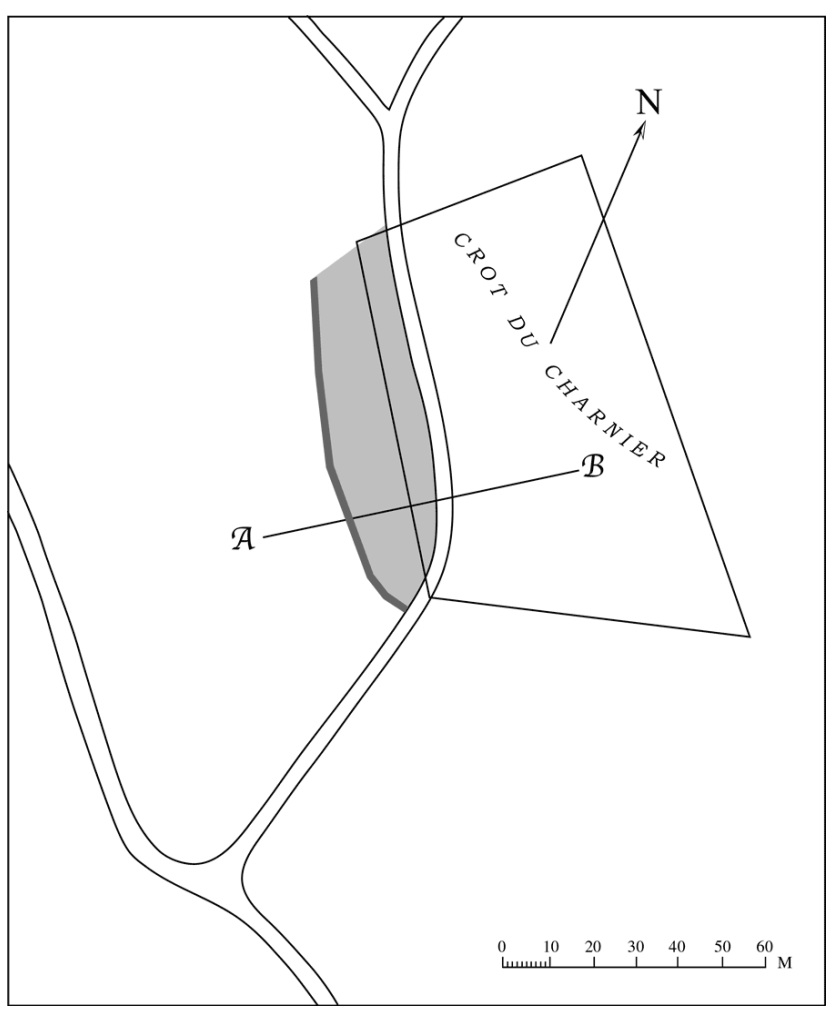

5 Much of the material in the Field Museum's collection is ascribed to one of four "foyers du renne", hearths ostensibly of the Solutrean phase. As with much surrounding the early excavations at Solutré, the designation of these hearths as Solutrean remains suspect. Some of these foyers are further divided into levels, "couches", which may represent either artificial spits imposed by the excavators or true archaeological levels, reflecting soil, use, or depositional changes. Combier has suggested (e.g. Combier 2002), based on later excavations, that much of the material in these hearths may be Magdalenian or later, although analysis of lithics from these hearths held by the Field Museum did not identify any Magdalenian inclusions, finding only tools of the Solutrean industry (Dalton 1968). Additional catalog lots at the Field Museum are designated as belonging to a particular "foyer/couche du cheval", which, with a few exceptions, seem to describe the "horse magma" and accompanying hearths below the Solutrean occupation levels. Arcelin described these levels as Mousterian, Combier calls the hearths instead Perigordian or Aurignacian and the magma Gravettian, but suffice to say that they appear to be pre-Solutrean. The wrinkle, both literally and figuratively, is that in at least two different lots of Field Museum material, the "chevaux" contexts are noted as lying above the Solutrean hearths. Such notations necessarily suggest that either the stratigraphy of the 1896 trench was poorly understood and documented and/or that the formation processes of this portion of the site include the type of slumpage and inversion noted by Combier as occurring elsewhere at Solutré (Combier 2002). Finally, some remaining materials have particularly enigmatic designations, including "Angleterre", "Foyer du Lapon-4th Fouille", or simply "foyer", the meanings of which have been lost.

The specimens of interest to this work, two contiguous fragments of a juvenile human mandible, no. 215505, were rediscovered in late 2002 during the reorganization of 
European archaeological collections in the Department of Anthropology at the Field Museum of Natural History. The bone was found, along with thirteen pieces of apparently Solutrean period debitage, in a soil sample from Solutré labeled as coming from the " $4 e$ foyer du Renne, $3 e$ Couche". The mandible was previously observed at this same location by Joanna Dalton, as is mentioned in her unpublished 1968 MA thesis, although no further analysis of the specimen was performed as a result of that discovery. In early 2003, following the most recent rediscovery of these pieces, a detailed morphological and radiographic analysis was preformed, and AMS radiocarbon dating of the specimen was performed at the Oxford University Radiocarbon Accelerator Unit in November of the same year.

\section{Osteological analysis}

7 The specimen is comprised of approximately $60 \%$ of a juvenile mandible, broken postmortem into two fragments (fig. 4). The larger posterior fragment includes a substantial portion of the right ascending ramus (although the most superior portions of both the coronoid and condylar processes are absent) and the majority of the right mandibular corpus through a break that bisects the socket of the right $\mathrm{I}_{2}$ and the crypt of the right $\mathrm{C}_{\mathrm{x}}$. The smaller anterior fragment abuts the mesial end of this break and includes the entirety of the mental trigone and the beginning of the proper left portion of the dental arch through a break that passes through the thin section of bone remaining between the crypts of the left $C_{x}$ and left $P_{1}$, between the left $I_{2}$ and left $d c_{x}$.

Due to the limited nature of this specimen, dental development was the sole means by which biological age could be assessed. Given the lack of precision of dental ageing techniques based solely on the timing of tooth eruption, the biological age of this specimen was assessed instead by means of a radiographic examination of the state of deciduous and permanent dental mineralization, development, and resorption using the techniques of Moorrees, Fanning, and Hunt 1963a (as reworked in Smith 1991) and Moorrees, Fanning, and Hunt 1963b (fig. 5). The developmental stages of two deciduous $\left(\mathrm{dm}_{1}\right.$ and $\left.\mathrm{dm}_{2}\right)$ and four permanent $\left(\mathrm{P}_{1}, \mathrm{P}_{2}, \mathrm{M}_{1}\right.$, and $\left.\mathrm{M}_{2}\right)$ mandibular teeth were assessed, yielding the stage assessments and accompanying male and female mean ages detailed in Table 1. For the present purposes, the assessed developmental states and resultant ages derived from the individual roots of multi-root teeth have been averaged. The resulting age range for this individual is 6.7-9.4 years, with an average of 8.3 years. An age at the upper end of this range (in excess of 8 years) is independently supported both by the mild wear on the mesio-buccal cusp of the $\mathrm{M}_{1}$, the presence of which suggests that that tooth must have been in occlusion for some significant period of time following its eruption around age 6, and also by the first possible hint of onset of mineralization in the crypt of the $\mathrm{M}_{3}$, which occurs, on average, just after 9 years of age (Smith 1991). 
Figure 4 - Superior view, FM n o. 215505 (photograph W. Pestle, drawing J. Seagard). Figure 4 - Vue de dessus, FM n 0215505 (photo W. Pestle, dessin de J. Seagard).
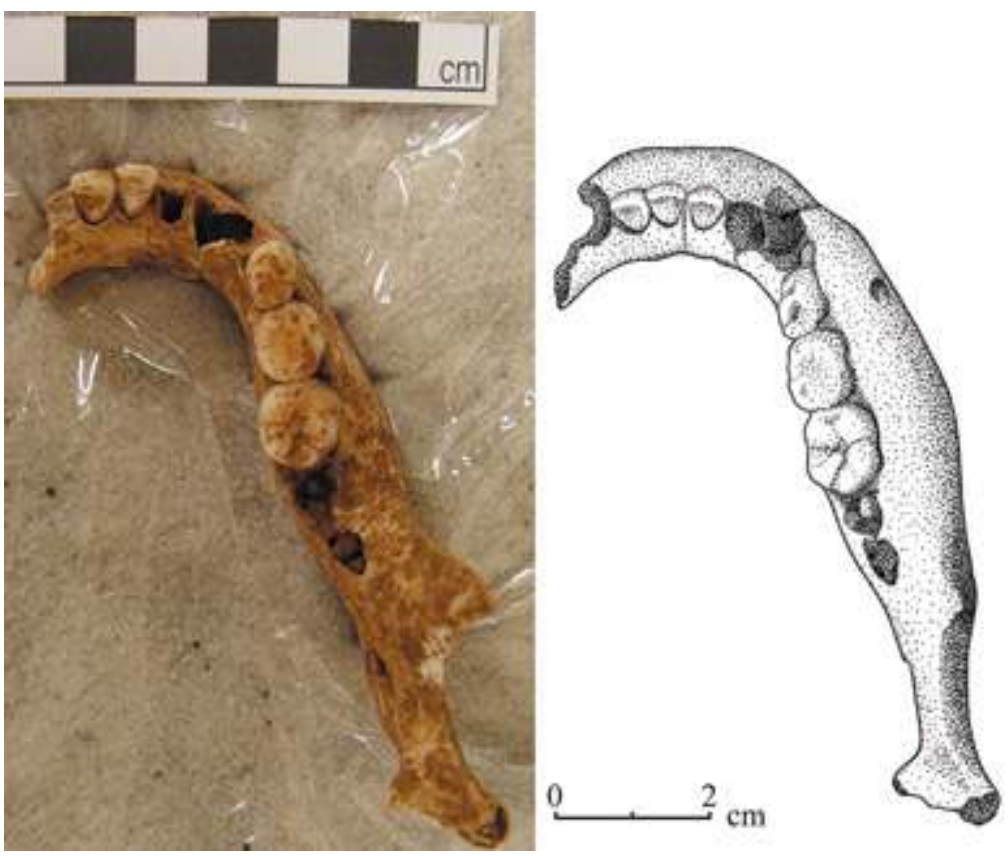

Figure 5 - Medio-lateral radiograph, FM no. 215505 (photograph W. Pestle). Figure 5 - Radiographie medio-latérale, FM n² 215505 (photo W. Pestle).

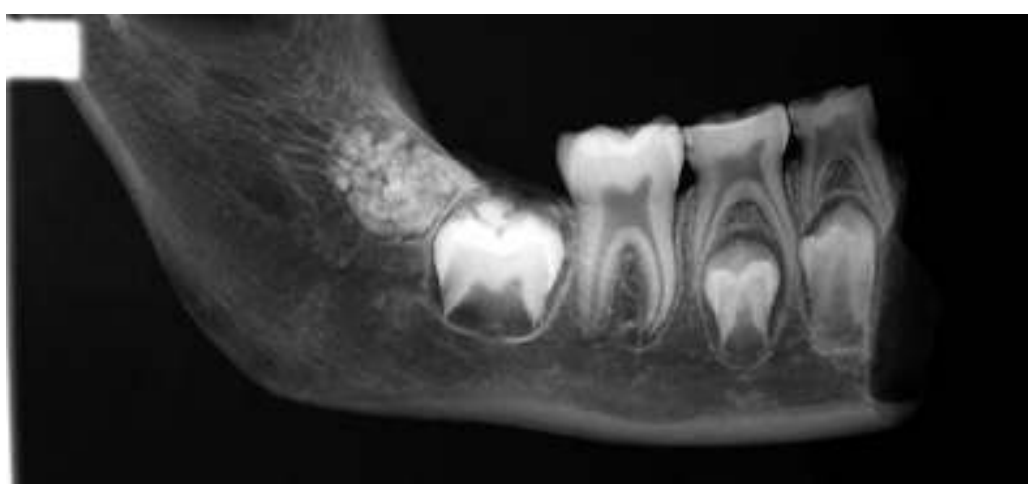

Table 1 - Dental development age assessment using the techniques of Moorrees, Fanning and Hunt 1963, and Smith 1991.

Tableau 1 - Evaluation de l'âge selon le développement dentaire utilisant les techniques de Moorrees, Fanning et Hunt 1963 et Smith 1991.

\begin{tabular}{|c|c|c|c|}
\hline & Stage & Age (M) & Age (F) \\
\hline $\mathrm{M} 2$ & $\mathrm{Cli}$ & 8,7 & 8,4 \\
\hline $\mathrm{M} 1$ & $\mathrm{Ac}$ & 9,4 & 8,7 \\
\hline $\mathrm{P} 2$ & $\mathrm{R} 1 / 4$ & 8,6 & 8,2 \\
\hline $\mathrm{P} 1$ & $\mathrm{R} 1 / 2$ & 9,3 & 8,7 \\
\hline $\mathrm{dm} 2$ & $\mathrm{Res} 1 / 4$ & 7,2 & 6,7 \\
\hline $\mathrm{dm} 1$ & $\mathrm{Res} 1 / 2$ & 8 & 7,5 \\
\hline
\end{tabular}


9 Areas of periodontal disease, visible in the osteological record as alveolar resorption, were observed at both the $\mathrm{dm}_{1}$ and in the area of the incisors, with the most pronounced appearance at the level of the right $\mathrm{I}_{1}$. While some of the observed bone loss is, no doubt, the result of taphonomic processes, the moth eaten appearance of alveolar bone is consistent with either periodontal disease, an ankylosed frenum, or both (Mintz et al. 2005). The latter etiology, commonly resulting in a "lip tied" condition which promotes the retention of food residues and the proliferation of bacteria, would also be consistent with the extremely robust appearance of the chin of this specimen (American Academy of Pediatric Dentistry 2005). Several carious lesions were observed on this specimen, one on the occlusal surface of the right $M_{1}$, between the mesio-buccal and mesio-lingual cusps, and three additional small buccal pit caries on the right $\mathrm{dm}_{1}, \mathrm{dm}_{2}$, and $\mathrm{M}_{1}$. The presence of these carious lesions is suggestive of a recent origin for this specimen, as one would not expect this number of dental caries in an individual who had consumed the typically low-carbohydrate, low-sugar diet of the Upper Paleolithic (Hillson 1996)

Several aspects of the pathological presentation of this specimen stem from a possible case of malocclusion. This diagnosis is supported by the heavier than expected wear on the mesio-buccal cusp of the $\mathrm{M}_{1}$, which appears markedly different from the other cusps of the same tooth. While this wear could be the result of a high grit diet (in which case, an accelerated, but non-pathological, wear progression would begin, as normal, with the mesiobuccal cusp of $M_{1}$ (Hillson 1996), a possibility supported by the wear found on the $\mathrm{dm}_{1}$ and $\mathrm{dm}_{2}$, it could also stem from malocclusion with the corresponding maxillary teeth ( $\mathrm{dm} 2$ or $\mathrm{M} 1$ ). Either etiology (facial dysplasia, prognathism, or malocclusion) could explain the presence of heavy wear on both central incisors resulting in the exposure of dentin and the production of a knife-edged appearance of their occlusal surfaces (Garcia Pola et al. 2002).

11 Finally, this specimen possesses a notable, albeit non-pathological, non-metric variation in the form of a small (approx. $1 \mathrm{~mm}$ ) fenestration on the lingual aspect of the mandibular ramus at the apex of the distal root of $M_{1}$. This aperture would have, in life, provided the opening by which a branch of the lingual nerve would have individually innervated the first molar. This trait, present in approximately $2 \%$ of modern human adults, has only infrequently been recognized in the paleopathological record (Kay 1974).

\section{Direct AMS radiocarbon dating}

12 The sediment that made up the soil sample in which this specimen was re-discovered was notably red in color, which we took as a preliminary indicator of the post-Glacial date eventually ascribed to this specimen (Jayet 1951, Dalton 1968). AMS dating of a sample (OxA-13424) from this specimen was performed in late 2003/early 2004 by the Oxford University Radiocarbon Accelerator Unit. Chemical pretreatment, target preparation, and AMS measurement were performed following procedures detailed in Hedges et al. 1989, Ramsey et al. 2000a, Ramsey et al. 2000b, and Hedges et al. 1992. The uncalibrated result in radiocarbon years BP (Before Present-AD1950) is as follows: OxA-13424, human bone, 嚂13 C =-18.7 \%o, $1676 \pm 36$ BP. 
When calibrated using Oxcal v3.10 of C. Bronk Ramsey and the atmospheric data of INTCAL04 (Reimer et al. 2004), the sample is found to date to the period between $240 \mathrm{AD}$ and $540 \mathrm{AD}$ (3-sigma). For the purpose of comparison, faunal specimens in the Field Museum's collection from several of the foyer du renne of Veillerot's excavation were also dated by AMS. One of these faunal specimens (OxA-13298), the calcaneus of a Cervus elaphus, from a foyer $d u$ Renne, yielded a definitive date of the Solutrean phase, between $22200 \mathrm{cal} \mathrm{BC}$ and $20900 \mathrm{cal} \mathrm{BC}$. Another sample, the maxilla of an Equus sp. (OxA-13299), from the $4 e$ foyer du Renne, 6e Couche, dated to between $16100 \mathrm{cal} \mathrm{BC}$ and $14800 \mathrm{cal} \mathrm{BC}$, the heart of the Magdalenian phase.

\section{Conclusions and discussion}

Specimen no. 215505 represented the tantalizing possibility of the presence, in a legitimately Solutrean level from the site of Solutré, of human remains. The authenticity of similar specimens has been the subject of great debate in scholarly journals for over a century (Arcelin 1878, Riquet 1955). Perhaps not surprisingly, all available evidence in this instance appears to rule out the possibility of the specimen's Solutrean antiquity. The apparently post-Glacial character of the sediments in which it was discovered and the presence of such a large number of carious lesions in the dentition of this individual are both indicative of a relatively recent origin for this specimen, a conclusion that is confirmed by the late antique provenance determined by AMS dating.

15 Given the stark contrast between the date of the human mandible in question and the much older dates of the faunal materials discovered in presumably close context, it is reasonable to assume that the human mandible, no. 215505, represents a much later burial which intruded into bona fide Upper Paleolithic strata. While this result lessens the significance of the individual specimen, it does begins to offer some insight into the nature and stratigraphy of the archaeological levels of Solutré as is represented in collections at the Field Museum of Natural History. Further research is presently being conducted on the mass of faunal materials at the Field Museum in an attempt to reconstruct fully the stratigraphy and absolute chronology of the materials recovered in such a slipshod manner over a century ago.

\section{BIBLIOGRAPHY}

AMERICAN ACADEMY OF PEDIATRIC DENTISTRY 2005- Official Guideline on Pediatric Oral Surgery.

ARCELIN A. 1878- Les sepultures de l'age du renne de Solutré. Revue des questions scientifiques, t. 3 , p. 349-399.

ARCELIN A. 1890 - Les nouvelles fouilles de Solutré (Prés Macon, Saône-et-Loire). L'Anthropologie, 1, p. 295-313. 
COMBIER J. 2002 - Solutré, site témoin des origines de l'archéologie préhistorique. In : J. Combier and A. Montet-White (Eds.), Solutré: 1968-1998. Mémoire de la Société Préhistorique Française no. 30, p. $17-26$.

DALTON J. 1968 - The Field Museum Collection from Solutré. Unpublished MA thesis, University of Chicago.

GARCIA POLA, M., GONZALEZ GARCIA, M., GARCIA MARTIN J., GALLAS M., and J. LESTON 2002- A study of pathology associated with short lingual frenum. Journal of Dental Childhood, 69(1), p. 59-62.

Hedges, R.E.M., M.J. Humm, J. Foreman, G.J. VanKlinken and C.R. Bronk 1992 - Developments in sample combustion to carbon dioxide, and in the Oxford AMS carbon dioxide ion source system. Radiocarbon, 34(3), p. 306-311.

Hedges, R.E.M., I.A. Law, C.R. Bronk, and R.A. Housley 1989 - The Oxford accelerator mass spectrometry facility : Technical developments in routine dating. Archaeometry, 31(2), p. 99-113.

HILLSON S. 1996 - Dental Anthropology. Cambridge University Press, Cambridge UK.

JAYET A. 1951 - Les Terres Rouges Superficielles de Vergisson et de Solutré (Sâone-et-Loire) France. Archives des Sciences, 4 (fasc. 6), p. 417-422.

KAY L.W. 1974 - Some anthropologic investigations of interest to oral surgeons. International Journal of Oral Surgery, 3, p. 363-379.

MINTZ S.M., SIEGEL M.A. and P.J. SEIDER 2005 - An overview of oral frena and their association with multiple syndromic and nonsyndromic conditions. Oral Surgery, Oral Medicine, Oral Pathology, Oral Radiology, and Endontology, 99(3), p. 321-324.

MOORREES C.F.A., FANNING E.A. and E.E. HUNT1963a - Age Variation of Formation Stages for Ten Permanent Teeth. Journal of Dental Research, 42, p. 1490-1502.

MOORREES C.F.A., FANNING E.A. and E.E. HUNT1963b - Formation and Resorption of Three Deciduous Teeth in Children. American Journal of Physical Anthropology, 21, p. 205-213.

RAMSEY C.B. 2005 - OxCal Program v.3.10 (Computer Program). URL http://www.rlaha.ox.ac.uk/ orau/oxcal.html.

Ramsey C.B., P.B. Pettitt, R.E.M. Hedges, G.W.L. Hodgins and D.C. Owen 2000a - Radiocarbon dates from the Oxford AMS system : Archaeometry datelist 29. Archaeometry, 42(1), p. 243-254.

Ramsey C.B., P.B. Pettitt, R.E.M. Hedges, G.W.L. Hodgins and D.C. Owen $2000 \mathrm{~b}$ - Radiocarbon dates from the Oxford AMS system : Archaeometry datelist 30. Archaeometry, 42(2), p. 459-479.

Reimer, P. J., Baillie, M. G. L., Bard, E., Bayliss, A., Beck, J. W., Bertrand, C. J. H., Blackwell, P. G., Buck, C. E., Burr, G. S., Cutler, K. B., Damon, P. E., Edwards, R. L., Fairbanks, R. G., Friedrich, M., Guilderson, T. P., Hogg, A. G., Hughen, K. A., Kromer, B., McCormac, F. G., Manning, S. W., Ramsey, C. B., Reimer, R. W., Remmele, S., Southon, J. R., Stuiver, M., Talamo, S., Taylor, F. W., van der Plicht, J. and C.E. Weyhenmeyer 2004 - IntCal04 Terrestrial radiocarbon age calibration, 26 - 0 ka BP. Radiocarbon, 46, p. 1029-1058.

RIQUET R. 1955- Les squelettes “Aurignaciens” de Solutré. In : M. Thoral, R. Riquet, and J. Combier (Eds.), Solutré. Travaux de Laboratoire de Géologie de la Faculté des Sciences de Lyon N.S. t. 2 (pt. 1), p. 1-92.

SMITH B.H. 1991 - Standards of Human Tooth Formation and Dental Age Assessment. In : M.A. Kelley, and C.S. Larsen (Eds.) Advances in Dental Anthropology, New York : Wiley-Liss, p. 143-168. 
VAUVILLÉ M.O. 1896 - Renseignements et observations sur le gisement préhistorique de Solutré (Saône-et-Loire). Bulletin de la Societé d' Anthropologie de Paris, 4eme serie t. VII, p. 600-605.

\section{APPENDIXES}

\section{Version française abrégée}

Solutré est connu en tant que site éponyme de l'industrie lithique solutréenne correspondant à une période du Paléolithique supérieur. Près de 150 ans de fouilles à Solutré ont mis en évidence une occupation humaine datant du Pléistocène tardif, l'existence d'un approvisionnement en nourriture et de fabrication d'outils dans le Mâconnais. A ce jour, toutefois, aucun reste humain n'a été découvert dans les niveaux solutréens. Plusieurs «candidats» ont bien été proposés (Arcelin 1878) mais aucun n'a résisté à un sérieux examen scientifique (Riquet 1955). Des restes humains provenant de Solutré, récemment redécouverts, sont examinés ici dans l'espoir que leur ancienneté puisse nous aider à combler les lacunes de nos connaissances sur la vie au Paléolithique supérieur dans le sud-ouest de l'Europe.

Le spécimen considéré dans le cadre de cette étude a été redécouvert à la fin de l'année 2002 au Field Museum of Natural History. Il est constitué de deux fragments contigus provenant d'une mandibule d'un être humain juvénile. Ce spécimen a été mis au jour lors de fouilles archéologiques effectuées en 1896 au Crot-du-Charnier par un certain M. Veillerot. En utilisant le seul document qui nous est parvenu au sujet de ces fouilles, une lettre de 1896 écrite par Monsieur O. Vauvillé, un membre de la Société d'Anthropologie de Paris, nous avons essayé de localiser l'endroit d'où proviendrait le spécimen. Il aurait été prélevé quelque part dans la zone sombre de la figure 3, à l'ouest de Crot-du-Charnier. S'appuyant sur une note trouvée avec le spécimen, décrivant le lieu de la découverte : «4e foyer du Renne, 3e couche», nous sommes confrontés à la possibilité, somme toute assez mince, que le spécimen puisse provenir d'une couche solutréenne.

Un examen ostéologique approfondi a permis d'établir que le spécimen appartiendrait à un individu âgé de 6,7 à 9,4 ans. Il a également révélé l'existence de caries et de problèmes dentaires provoqués peut-être par un cas de malocclusion et de maladie parodontale. La présence des caries est un indicateur de l'âge géologique du spécimen. De telles caries ne sont pas compatibles avec le régime alimentaire faible en glucide et notamment en sucre, d'un individu du Paléolithique supérieur.

L'âge du spécimen suggéré par l'examen pathologique est confirmé de manière frappante par la datation radiocarbone par spectrométrie de masse à accélérateur (AMS) d'un prélèvement (OxA-13424). Cette datation a été effectuée fin 2003/début 2004 par le Oxford University Radiocarbon Accelerator Unit en suivant les procédures détaillées par Hedges et al. 1989 ; Ramsey et al. 2000a ; Ramsey et al. 2000b ; Hedges et al. 1992. Les résultats radiocarbones non calibrés en années BP (Before Present - 1950) sont : OxA-13424, os humain, d 13C = -18,7\%o, $1676 \pm 36$ BP. Lorsque l'on utilise Oxcal v3.10 de C. Bronk Ramsey et les données atmosphériques de INTCAL04 (Reimer et al. 2004), la datation du prélèvement est située dans l'intervalle 240 - 540 calAD (3-sigma). Le spécimen $n^{\circ} 215505$ représentait donc la possibilité très excitante d'avoir découvert la présence de restes humains dans une couche solutréenne du site de Solutré. 
Malheureusement, nos travaux n'ont pas permis d'établir une datation correspondant à la période solutréenne pour ce spécimen. Des éléments de faunes (dont un maxillaire d'Equus sp. (Oxa-13299) découverts dans le même contexte du 4e foyer du Renne, 6e couche, ont été datés entre 16100 cal BC et 14800 cal BC (période magdalénienne). La différence de datation entre la mandibule humaine $n^{\circ} 215505$ et la faune laisse penser à une inhumation plus récente qui constituerait une intrusion dans une couche paléolithique supérieure.

\section{ABSTRACTS}

Nearly 150 years of excavation at the Upper Paleolithic type-site of Solutré has yielded substantial evidence for Late Pleistocene human occupation, food procurement, and tool manufacture in the Mâconnais. To date, however, no human skeletal material from the Solutrean phase of this eponymous site has been discovered. Among the finds curated by the Field Museum of Natural History resulting from a relatively obscure and poorly documented excavation conducted at the heart of the site in 1896 is, however, a human juvenile mandible which had, until quite recently, escaped both notice and study. While the scanty stratigraphic information available for the specimen indicates that it comes from a Solutrean level, recently conducted radiometric analysis (an AMS date of $1676 \pm 36 \mathrm{BP}$, uncalibrated) suggests a much more recent origin.

\section{INDEX}

Mots-clés: Solutré, Solutréen, radiocarbone, restes humains

Keywords: Solutré, Solutrean, radiocarbon, human remains

\section{AUTHORS}

\section{WILLIAM PESTLE}

Department of Anthropology, University of Illinois at Chicago, 1007 W. Harrison St., Room 2102, Chicago, IL 60612, USA - wpestl2@uic.edu

\section{MICHAEL COLVARD}

Department of Oral Medicine and Diagnostic Sciences, College of Dentistry, University of Illinois at Chicago, 569E DENT, Chicago, IL 60612, USA. - colvard@uic.edu

\section{PAUL PETTITT}

Department of Archaeology, University of Sheffield. Northgate House, West Street, Sheffield S1 4ET - P.pettitt@sheffield.ac.uk 